\title{
An Empirical Investigation on the Effect of Land Size on its Productivity of Coconut Plantations in Sri Lanka
}

\author{
K. V. N. N. Jayalath ${ }^{1}$, P. M. E. K. Pathiraja ${ }^{1}$, U. K. Jayasinghe-Mudalige ${ }^{2}$ and M. T. N. Fernando ${ }^{3}$ \\ ${ }^{1}$ Agricultural Economics \& Agribusiness Division, Coconut Research Institute of Sri Lanka, Lunuwila, Sri Lanka, 61150 \\ ${ }^{2}$ Dept. of Agribusiness Management, Faculty of Agriculture \& Plantation Management Wayamba University of Sri Lanka, \\ Makandura, Gonawila, Sri Lanka (NWP)
}

${ }^{3}$ United Nations Development Project, Asia \& Pacific Regional Centre, 23, Independence Avenue, Colombo 7

\begin{abstract}
The objective of this study was to examine empirically the relationship between productivity and size of coconut lands in Sri Lanka. The primary data collected by means of a field survey conducted by the Coconut Research Institute of Sri Lanka from 69 coconut cultivations located in the Kurunegala, Puttalam and Gampaha districts in 2004/05 were used. These cultivations were categorized into three groups depend on their size, namely: (1) Home gardens [<2 ac]; (2) Smallholdings [2 $20 \mathrm{ac}$ ], and (3) Estate sector [>20 ac]. The empirical model explaining the relationship between productivity and land size and several other variables that can have an impact on productivity (e.g. land suitability class, age of the plantation, number of bearing palms/ac, agro-ecological region, availability of labor and management practices adopted by growers such as fertilizer application, soil and moisture conservation and pest $\&$ disease control etc.) was tested. The results of analysis show that there exists a significant negative relationship between land size and productivity of coconut lands in Sri Lanka for home gardens and smallholders. The minimum productive land size was 21 ac, where the estimated productivity was 1052 nuts/ac/year. On the other hand, the productivity of estates increases as the land size increases from 21 ac onwards up to 40 ac. Only the availability of labor was significantly affected on productivity, while the impact of other factors was insignificant in this respect. The results imply that policymakers and regulatory agencies responsible for coconut industry in Sri Lanka must take efforts to secure large estates from unnecessary fragmentation, and fragmentation of smallholding may be allowed if the separated lands are remained predominantly with coconut.
\end{abstract}

Keywords: Coconut industry in Sri Lanka, Land fragmentation, Land size, Productivity, Smallholders 


\section{INTRODUCTION}

Coconut is one of the commercially important plantation crops in Sri Lanka. Currently, the contribution of coconut sector to the Gross Domestic Product (GDP) is about $1.4 \%$. It is also responsible for nearly $3.1 \%$ of the total foreign exchange earnings in Sri Lanka in 2009 (Central Bank of Sri Lanka, 2009). The total land extent under coconut in the country has been reduced from 416,253 ha to 394,836 ha from 1982 to 2002, which is a reduction about $5 \%$ (21,417 ha).

The coconut lands in Sri Lanka are categorized as "Smallholding Sector [SH] (i.e. < $20 \mathrm{ac}$ ) and the Estate Sector (ES) (i.e. $>20 \mathrm{ac}<$ $50 \mathrm{ac})$. Under this classification, almost $99 \%$ of coconut growers become smallholders, and the extent under smallholdings is $81.9 \%$ of the total coconut land extent. The total extent of coconut lands under the estate sector has been reduced from 103,129 ha in 1982 to 71,347 ha in 2002, while that of smallholdings sector has been increased from 313,124 ha to 323,489 ha during this period. This has been caused by, amongst the other reasons, fragmentation of lands that took place extensively in the recent past.

Even though the extent of land under coconut has been decreased gradually, the national production of coconuts has shown a slight increase during the last 20 years suggesting that the productivity of existing coconut lands has increased overtime. Nevertheless, the potential per capita availability of coconut has been reduced overtime indicating that the production has not been increased sufficiently to meet the requirement of growing population.
Although literature suggests the existence of a negative relationship between the size of a farm and its productivity (Bardhan, 1973; Zyl et al, 1996), there is no empirical evidence to prove this in the context of coconut industry in Sri Lanka. If this hypothesis is true, we can predict that smallholders are more productive than larger estates with over 20 acres in extent. In a situation where, the kernel-based coconut processing industry has widened its scope into different products, the major challenge facing the coconut industry of Sri Lanka at present is to increase the national production to satisfy the demand of domestic culinary nuts and the demand of expanding coconut-based industries. Further, the government, through various initiatives, attempts to expand coconut cultivation into non-traditional areas such as Anuradhapura and Moneragala, and newly liberated areas in the Northern and Eastern Provinces. However, the scarcity of cultivable lands limits this effort. Therefore, raising productivity of existing coconut lands is inevitable and under these circumstances the information on land size on productivity of coconut lands is important. The purpose of this study was to examine empirically the relationship between size of coconut land and its overall productivity.

\section{MATERIALS AND METHODS}

Theoretical Framework: The coconut lands in Sri Lanka are classified into two major categories: (1) "smallholding sector" ( $<20 \mathrm{ac})$, and (2) "estate sector" $(20-50 \mathrm{ac})$. Within the category (1), the lands that are less than 2 ac can be further classified as "home gardens" (HG). For the purpose of this analysis, therefore, all these land categories were considered. The 
productivity of coconut cultivation may depend on many other factors such as variety, annual rainfall, age of the plantation, soil type, agroecological region, and management practices (e.g. fertilizer application, soil and moisture conservation, weed control and pests \& disease control) (Abeywardane, 1971; Samarajeewa et al., 2001). However, many of these factors may be beyond the control of a coconut grower, irrespective of size of the land in terms of efforts to enhance the land productivity. Based on the type of soil, the coconut lands are, categorized into five "Land Suitability Classes" (LSC), namely: (a) S1 = highly suitable; (b) S2 = suitable to highly suitable; (c) S3 = suitable; (d) S4 = moderately suitable, and (e) S5 = marginally suitable (Somasiri et al., 1994). The productivity of a land can, therefore, be significantly varied with respect to which LSC it belongs to, and lands that belong to LSC in higher order are more productive and vice versa.

The relationship between land size and other variables that determines the productivity of a coconut land can be expressed as follows.

$\mathrm{PRD}=\mathrm{f}(\mathrm{LAS}, \mathrm{LSC}, \mathrm{AGE}, \mathrm{NP}, \mathrm{AER}, \mathrm{LAB})$

Where, PRD is productivity of the land $i$ (measured in terms of nuts/acre) and LAS is the size of the land (ac). LSC denotes the land suitability class, AGE is age of the plantation, NBP is number of bearing palms/ac, AER is agro-ecological region and $\mathrm{LAB}$ is usage of labor (both family and hired labor)/ac/year. We assume that AGE to have a negative relationship with the productivity and NBP to have a positive impact. In addition, a number of management practices adopted by the growers, were considered in the model by means of a series of dummy variables, where $1=$ if adopted and $0=$ if otherwise.

\section{DATA COLLECTION AND ANALYSIS}

The primary data from 69 coconut growers were used to examine this (economic) problem, through a survey administered by the Coconut Research Institute of Sri Lanka (CRISL) in $2004 / 05$. The survey covered a wide range of major coconut growing areas located in the coconut triangle in Sri Lanka, including the Kurunegala, Puttalam and Gampaha districts, which represent $56.4 \%$ of the total extent under coconut cultivation. A farm record book prepared by the CRISL was distributed to the coconut growers to collect valid and reliable data, especially to cover the areas of: (i) description of the holding (personal data, location of farm, land size, land suitability class, agro-ecological region); (ii) monthly work of family and hired labor; (iii) crop-wise harvesting and crop disposal data, and (iv) adoption of management practices.

Both qualitative and quantitative data analysis techniques were employed to analyze the data. For the purpose of estimation of coefficients of the models, the Regression Analysis was used with the Ordinary Least Square techniques.

\section{RESULTS AND DISCUSSION}

\section{Descriptive Statistics}

Out of 69 coconut cultivations selected in this study, nearly $55 \%$ of lands were classified under the category of smallholders while $16 \%$ of the land under home garden category. 
The lands under estate sector were 29\%. With respect to the Land Suitability Class (LSC), the majority of coconut lands in the sample belong to the S3. In home garden sector, $73 \%$ of the lands are in S3 land suitability class while only $9 \%$ of the land belongs to S2. The percentage of coconut lands under S3 land suitability class in smallholding and estate sector was $55 \%$ and $60 \%$ respectively.
The mean productivity of lands in the sample was 1966 nuts/ac/year (Standard Deviation = 497). The mean land size was $14.3 \mathrm{ac}$, where the smallest and largest lands were 0.75 ac and 50 ac, respectively. The age of coconut plantations ranged from 20 to 70 years with the mean of 46 years. Number of bearing palms/ac was high as 97 in some holdings while it was as low as 23 in some others (Table 1).

Table 1: Descriptive statistics of the variables in the model

\begin{tabular}{lcccc}
\multicolumn{1}{c}{ Variables } & Mean & Minimum & Maximum & SE $^{+}$ \\
\hline Productivity (Nuts/ac/year) & 1966 & 1052 & 5928 & 497 \\
Land size (Ac) & 14.3 & 0.75 & 50.0 & 15.8 \\
Age of plantation (Years) & 46.5 & 20.0 & 70.0 & 9.6 \\
Bearing no of palms per acre & 54.0 & 23.0 & 97.0 & 13.1 \\
Labor use (Man days /ha / year) & 17.29 & 2.47 & 118.56 & 8.1 \\
\end{tabular}

The mean age of the plantations of the three different sectors was between 43 and 52 years (Table 2). The average number of bearing palms/ac was more or less similar in three sectors. The highest labour use of 12 man days/ac was observed in home gardens.

Table 2: Descriptive statistics of the sectors

\begin{tabular}{lccc}
\hline \multicolumn{1}{c}{ Variables } & \multicolumn{3}{c}{ Mean $\left(\mathbf{S E}^{+}\right.$) } \\
\hline & Home gardens & Smallholdings & Estates \\
Age (years) & 50 & 43 & 52 \\
& $(5.49)$ & $(10.23)$ & $(6.37)$ \\
Number of bearing palms (per ac) & 56 & 53 & 53 \\
& $(11.22)$ & $(13.53)$ & $(14.23)$ \\
Labor use (Man days /ac / year) & 12 & 7 & $(4.27)$ \\
\hline
\end{tabular}

The degree of adoption of various cultural practices amongst the coconut cultivations varied substantially. Smallholder coconut growers having less than 2 ac of land had not adopted proper 
mechanisms to control pests \& diseases and/or appropriate soil and moisture conservation measures in their cultivations. The adoption of right amount of fertilizer and controlling of weeds in the cultivation were, at a satisfactory level in the estate sector (Table 3).

Table 3: Adoption of recommended cultural practices

\begin{tabular}{lccccc}
\hline $\begin{array}{c}\text { Type of } \\
\text { cultivation }\end{array}$ & $\begin{array}{c}\text { Fertilizer } \\
\text { application } \\
(\%)\end{array}$ & $\begin{array}{c}\text { Weed } \\
\text { control } \\
\mathbf{( \% )}\end{array}$ & $\begin{array}{c}\text { Pest \& disease } \\
\text { management } \\
\mathbf{( \% )}\end{array}$ & $\begin{array}{c}\text { Moisture } \\
\text { conservation } \\
(\%)\end{array}$ & $\begin{array}{c}\text { Soil } \\
\text { conservation } \\
(\%)\end{array}$ \\
\hline Home gardens & 36 & 36 & 0 & 0 & 0 \\
Smallholders & 57 & 66 & 7 & 7 & 3 \\
Estates & 70 & 90 & 2 & 10 & 5 \\
\hline
\end{tabular}

The level of productivity of each cultivation was plotted against the size of the land (Fig. 1), where the respondents $(n=69)$ were arranged in ascending order. It shows that the productivity of coconut lands tend to decrease (i.e. negative trend) as the land size increases. The Pearson Correlation Coefficient between productivity and land size was -0.513 which indicates significant $(\mathrm{p}=0.05)$ negative relationship.

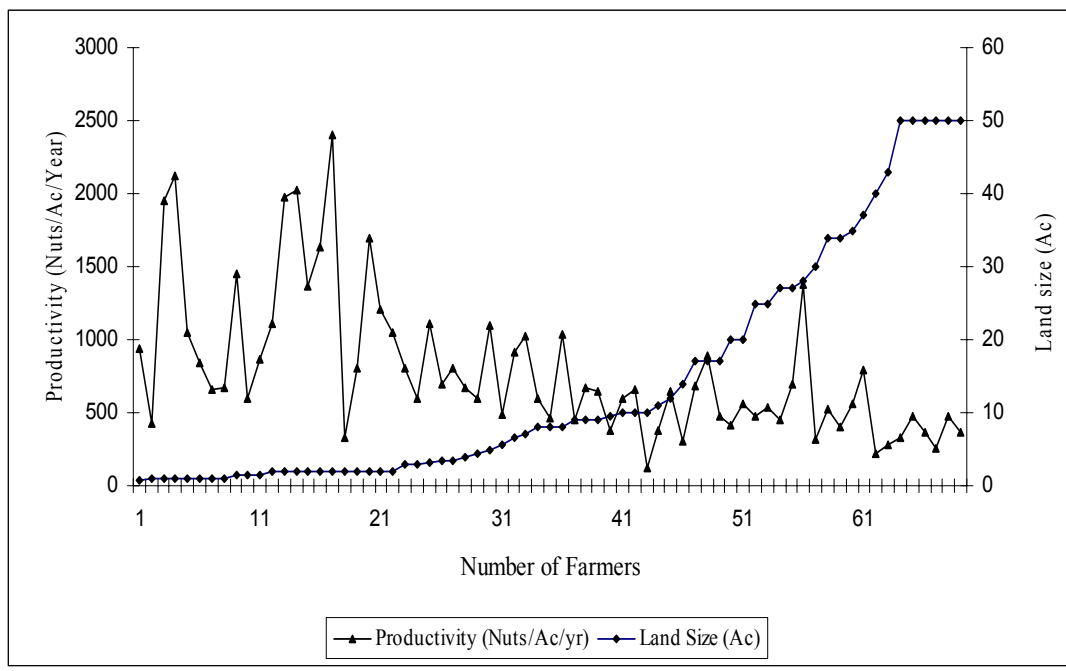

Fig 1: Variation in coconut land productivity with the increase of land size

\section{Estimates of Coefficients of Variables}

Table 4 reports the results from Regression Analysis between the productivity and land size for the different functional forms considered in this analysis. 
Table 4: Results of the regression analysis

\begin{tabular}{|c|c|c|c|}
\hline Functional Form & Coefficient & $\begin{array}{l}\text { Estimated } \\
\text { Coefficient } \\
\text { (SE) }\end{array}$ & Adjusted $\mathbf{R}^{2}$ \\
\hline \multirow[t]{2}{*}{ Linear } & $\beta_{0}$ & $\begin{array}{r}1013.74 * * * \\
(69.88)\end{array}$ & 0.251 \\
\hline & $\beta_{1}$ & $\begin{array}{r}-16.09 * * * \\
(3.32)\end{array}$ & \\
\hline \multirow[t]{3}{*}{ Quadratic } & $\beta_{0}$ & $\begin{array}{r}1161.46^{* * * *} \\
(85.09)\end{array}$ & 0.321 \\
\hline & $\beta_{1}$ & $\begin{array}{r}-48.07 * * * \\
(11.9)\end{array}$ & \\
\hline & $\beta_{2}$ & $\begin{array}{r}0.68 * * * \\
(0.25)\end{array}$ & \\
\hline \multirow[t]{4}{*}{ Cubic } & $\beta_{0}$ & $\begin{array}{r}1305.75 * * * \\
(104.35)\end{array}$ & 0.361 \\
\hline & $\beta_{1}$ & $\begin{array}{r}-103.15^{* * * *} \\
(26.98)\end{array}$ & \\
\hline & $\beta_{2}$ & $\begin{array}{r}3.81^{* *} \\
(1.41)\end{array}$ & \\
\hline & $\beta_{3}$ & $\begin{array}{r}-0.04 * * * \\
(0.019) \\
\end{array}$ & \\
\hline \multirow[t]{2}{*}{ Logarithmic } & $\beta_{0}$ & $\begin{array}{r}1226.68 * * * \\
(85.61)\end{array}$ & 0.359 \\
\hline & $\beta_{1}$ & $\begin{array}{r}-229.98 * * * \\
(37.04)\end{array}$ & \\
\hline
\end{tabular}

Note: *** Significant at $1 \%$ level

** Significant at $5 \%$ level

It highlights that the $\mathrm{R}^{2}$ value was increased by $7 \%$ as we changed the functional form from Linear to the Quadratic. The highest $\mathrm{R}^{2}$ value was reported under the Cubic functional form and as a result, this functional form was selected as the best fitted model:

$\mathrm{PRD}=1305.75-103.15 \mathrm{LAS}+3.81 \mathrm{LAS} 2-$ 0.04 LAS3

Fig. 2 depicts the relationship between productivity and land size using equation (7). This clearly shows that home gardens and smallholders are more productive than the larger estates. Interestingly, the land productivity decreases rapidly as the land size increases up to $20 \mathrm{ac}$, or in others within the smallholders category small farms performs better than large farms. The lowest productivity of 1052 nuts/ ac/year was reported in the land size of 21 ac. The results show that the average productivity of smallholding sector was 2075 nuts/ac/year. Amongst the estates, the productivity has been increased up to $40 \mathrm{ac}$ and then decreases. The average productivity of estates was 1094 nuts/ ac/year. Although the Fig. 2 explore that the productivity was decreasing again in the estate sector beyond 40 ac level, we did not have primary data to confirm this behavior. 


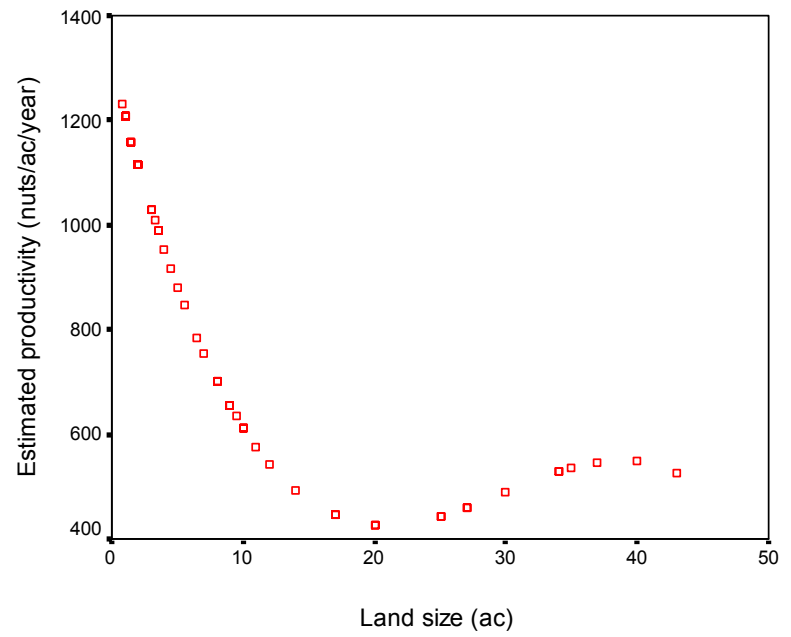

Fig 2 : Variation of estimated production with respect to coconut land size

Out of 12 explanatory variables included in the model, only the usage of labor (LAB) was significant $(\mathrm{P}=0.05)$ (Table 5).

Table 5: Impact of other variables on productivity

\begin{tabular}{lccc}
\hline Variable & $\begin{array}{c}\text { Estimated } \\
\text { Coefficient }\end{array}$ & SE & Significance \\
\hline LAS & $-85.77^{* * *}$ & 29.63 & 0.006 \\
\hline LSC & 175.02 & 92.16 & 0.063 \\
AGE & -6.29 & 5.17 & 0.229 \\
NBP & 6.14 & 3.92 & 0.123 \\
AER & 30.48 & 93.87 & 0.747 \\
LAB & $15.77 * *$ & 6.78 & 0.024 \\
\hline FER & 116.85 & 98.92 & 0.243 \\
WCL & 41.789 & 110.84 & 0.708 \\
PDC & -0.59 & 161.49 & 0.997 \\
MCN & 155.73 & 184.72 & 0.403 \\
SCN & 123.83 & 306.98 & 0.688 \\
FEN & -161.66 & 109.86 & 0.147 \\
Constant & 446.95 & 426.97 & \\
\hline Note** & & & 0.300 \\
\hline
\end{tabular}

Note: *** Significant at $1 \%$ level

** Significant at $5 \%$ level 
The usage of labor was highest in the home gardens (12mandays/ac/year). However, impact of each variable within a sector (i.e. home garden, smallholding and estate) may be significant. According to Table 2 there is no much difference of these variables among three sectors. The average age of the plantations were 50 to 55 years. The coconut yield stabilizes after 16 to 17 years of planting. Since the age of the plantations of the sample was similar a significant difference in age of plantations was not observed.

\section{CONCLUSIONS AND POLICY IMPLICATIONS}

Result from the analysis, suggest that the productivity of coconut lands in Sri Lanka depends significantly on the size of holding. The productivity was found to be highest in the home gardens and it decreases within the smallholding category. One of the major reasons behind this phenomenon may be non-availability of and/ or inability to hire required amount of labor to manage these smallholdings productively with all recommend practices since they tend to provide fewer returns on the investment. However, the results highlight that the productivity of coconut estates increases as the land size increases, in general, but at a lower rate. While the labor was having a significant impact on this behavior, none of the other variables show any significant impact. The descriptive statistics derived from the first hand information obtained from 69 coconut growers in the sample show that they did not much concern about adopting these practices in their cultivations.
The results emphasis the importance of securing large-scale estate sector to increase the production as well as the productivity, from one hand, and promotion of coconut cultivation amongst the smallholding sector, and specially within the home gardens, as they were proven to be highest productive in this respect. In a situation where the majority of coconut lands in the country belong to the smallholding sector and having understood the importance of estate sector, the regulatory agencies governing coconut industry in Sri Lanka may develop a set of two alternative policies for these two sectors (i.e. smallholding and estate) with respect to fragmentation of lands. For example, fragmentation of estates should not be allowed unless it is strongly justifiable as it has direct impact on total coconut production in the country. However, to make the agricultural and land policies to be realistic, fragmentation of smallholdings may be allowed on cases by case basis by considering the need, however, every effort must be taken to keep those fragmented lands under the coconut, may be under a different ownership.

Difference was not significant in variables of LSC and AER because most of the holdings were in land suitability class S3 and S4. This is a limitation of the study and can be improved by using stratified sampling instead of random sampling.

\section{ACKNOWLEDGEMENT}

Authors thank the Director and the Deputy Director (Research) of the CRISL for their approval and financial assistance to conduct this research. The support extended by Mr. S. 
D. J. N. Subasinghe, Agricultural Economics and Agribusiness Management Division of the CRISL to collect and code primary data is also highly appreciated. Also, a special thank is extended to the coconut growers who participated the study.

\section{REFERENCES}

Abeywardana, V. (1971). Yield variations in coconut. Coconut Research Institute of Sri Lanka. Ceylon Coconut Quarterly, 22: 97-103.

Bardhan, P. K. (1973). Size, productivity and returns to scale: An Analysis of farm-level data in Indian agriculture. J. of Political Economy, 81(6): 1 370-1 386.

Central Bank of Sri Lanka (2009). Annual Report. Colombo. Sri Lanka.

Samarajeewa, S. R., Thanaweera arachchi, P. T., Fernando, M. T. N. and Rathnasiri, N. G. S. C. (2001). Supply response analysis in coconut production. Sri Lanka Assoc. Adv. Sci., Proc. 57th Ann. Session, Part 1.

Somasiri, L. L. W., Nadarajah, N., Amarasinghe, L. and Gunathilake, H. A. J. (1994). Land suitability assessment of coconut growing areas in the coconut triangle in Sri Lanka. Coconut Research Institute, Lunuwila, Sri Lanka.

Zyl, J. V., Miller, B. R. and Parker, A. (1996). Agrarian structure in Poland. The myth of large farm superiority. Policy research Working paper. The World Bank. 